\title{
MEASUREMENT OF TEMPERATURE DISTRIBUTION WITHIN STEEL BOX GIRDER OF VISTULA RIVER BRIDGE IN CENTRAL EUROPE
}

\section{MACIEJ HILDEBRAND", ŁUKASZ NOWAK \\ Faculty of Civil Engineering, Wrocław University of Science and Technology, Wrocław, Poland}

Received 18 December 2019; accepted 30 March 2020

\begin{abstract}
Uneven temperature distribution in a structural element constitutes one of its load factors. Temperature fields occurring in structural elements lead to stresses and strains. The values of internal stresses are directly related to temperature distribution and degree of freedom for element deformation. The best way to get information about temperature distribution in an element is to take measurements on a real object. Such measurements have been run or are still taken over decades in various parts of the world, e.g. in Western Europe, USA, China, South America. In a number of cases, such examinations were carried out for objects constructed in warm or hot climate. It is a lot harder to find the results of measurements made in the countries with moderate and transitional climate, like in the Central or East-Central Europe. This paper presents measurement methodology and results gained for a large steel bridge located in the East European Plain, about $52.5^{\circ} \mathrm{N}$ northern latitude. Permanently installed contact sensors, temporary sensors, as well as pyrometry and thermography were used. An attempt was made to determine temperature
\end{abstract}

\footnotetext{
* Corresponding author. E-mail: maciej.hildebrand@pwr.edu.pl

Maciej HILDEBRAND (ORCID ID 0000-0001-8011-2464)

Łukasz NOWAK (ORCID ID 0000-0002-7732-640X)

Copyright (C) 2020 The Author(s). Published by RTU Press

This is an Open Access article distributed under the terms of the Creative Commons Attribution License (http://creativecommons.org/licenses/by/4.0/), which permits unrestricted use, 
distribution in a steel box girder of a bridge using thermovision technique. Approximate temperature distribution patterns in the main span girder were determined from thermal photographs taken. The most important results of examinations are the images of temperature fields in the main span girder related to solar radiation that first and foremost directly affects the bridge deck.

Keywords: bridge, environmental action, measurement, seasonal variations, steel box girder, temperature distribution, thermography.

\section{Introduction}

Bridge temperature measurements are quite well referenced in the literature and have relatively long tradition (Albrecht, Mangerig \& Zichner, 1992; Chen, 2008; Emerson, 1977; Ostapenko, Daniels, and Fisher, 1975; Prakash, 1986; Priestley, 1978; Zobel \& Sobala, 2002). On the one hand, these measurements are focused on determining the highest daily and seasonal temperature differences in global terms in order to predict potential changes in structure dimensions, especially the length of spans, since it is of fundamental importance while selecting accommodation capabilities of both expansion joints and bearings with respect to the highest mutual shifts of structure components. On the other hand, temperature measurements are used to assess deformations of isostatic structures or - in hyperstatic structures - to evaluate how internal forces induce loads in bridge components, e.g. in piers. The third area of temperature analyses refers to determination of temperature distribution in cross-sections of structural components in order to find stress fields which could be possibly created. Changes of temperature fields in bridge structures lead to various effects depending on the shape of such structures and materials used therein. Heat flow velocities, or the way in which the bridge draws energy from the environment and releases it, are different for steel and concrete structures. In general, it should be mentioned that elements of steel bridge structures may heat up to a higher temperature than those of concrete structures, on the other hand, the latter demonstrate higher heat capacity. It is worth mentioning that research on temperature applies not only to bridges but also to road surfaces, as described, for example, by Opara and Zieliński (2017).

Nowadays, bridge monitoring systems, described among others by Wenzel (2009) or Inaudi (2009), are generous data sources about temperatures in various points of structures. Usually these systems include modules for measurements of forces, strains, displacements, environmental impacts (wind); they also comprise temperature sensors for both air and structural components. Measurements of structure temperatures within the structure monitoring system are necessary 
to identify the changes in the static condition of a bridge, at the same Distribution Within time they can be used to gain information on temperature values, their variations and distribution over the structure as an independent factor affecting the structure load. Sensors for external air temperature are part of the weather station used to assess how natural environment affects the bridge structure. Sensors of internal temperatures (e.g. in steel box girders) can be coupled with humidity sensors used to evaluate corrosion risk. Sensors of structure temperatures can be coupled with strain sensors or constitute independent measuring units. In each of the above-mentioned cases, temperature is usually taken point-wise. While such approach is sufficient for general assessment of structure temperature variability, more thorough methods are required to determine temperature distribution along girder height. Point-wise temperature measurements with, for instance, two sensors located in the uppermost and lowermost points of a girder cross-section enable to find temperature difference in extreme fibres of a girder, which is already a component of structure load considered in the static analysis. However, modelling of such load could not be considered correct if its distribution along the girder height is not known more precisely.

\section{Temperature distribution in bridge girders - state of the art}

The problem of determining temperature distribution in a structure along the height of a bridge span cross-section is considered and solved both in theoretical and practical domains. One of the recent papers where this question has been widely described is the review of Zhou and Yi (2013) providing both the theoretical model and results of calculations based on the finite element method. The paper includes also the results of measurements for various types of bridge structures. Conclusions of this paper state that both theoretical models and design recommendations based on the available measurement data are far from satisfactory. Zhou and Yi (2013) have pointed out that, among other things, available data from the existing SHM (Structural Health Monitoring) systems about structure temperatures are applied to a very limited extent; innovatory bridge structures are designed using new materials (both structural and finishing ones); on the one hand, we observe climate changes, while on the other hand bridges are constructed in more and more distant parts of the globe in extreme natural conditions; and finally, there are no enough reliable theoretical models, which precisely represent the process of receiving energy 
and giving it back by a structure when solar radiation, external air temperature and wind speed are taken into account. All stated problems deserve further examination, including analysis of real structures in the field, especially in the regions of the world where such research was not intense.

The problems of thermal phenomena, especially in steel bridges (with concrete deck slab), have also been comprehensively described in, among others, Chen dissertation (2008), however, it should be kept in mind that examination results refer to bridges located in Texas, near Houston City, i.e. are subjective to local environmental conditions (at latitude $29^{\circ} \mathrm{N}$ ).

This section further presents information about thermal loads in bridge structures contained in the effective European Standard and considers one example of field examinations of bridge temperature carried out several decades ago in the tropical climate.

The European Standard, i.e. Eurocode 1 (2005), EN 1991-1-5, Action on structures, Part 1-5: General actions - Thermal actions, is the fundamental document providing information on temperature differences in bridge structures in Europe. Here, among other things, recommendations are provided on temperature differences between extreme points on the main girder height to be assumed and temperature profiles along girder height to be used. Two basic cases are considered, i.e. when the top part of the girder is warmer than its bottom, and when the top part of the girder is cooler than its bottom.

The Eurocode assumes that the temperature field in a girder results from superposition of several components including even component (homogenous temperature distribution in its cross-section), linear components of temperature difference (linear temperature distribution in vertical and horizontal directions of a cross-section), and nonlinear component of temperature difference (nonlinear temperature distribution in vertical direction of a cross-section).

For steel girders, it was specified in relation to the linear component of temperature difference that the temperature difference between the top and bottom plate in extreme cases is $18{ }^{\circ} \mathrm{C}$, when the top is warmer than the bottom, and $13{ }^{\circ} \mathrm{C}$, when the top is cooler than the bottom of a girder. In turn, when nonlinear component is considered, the temperature difference between the same elements may amount to $24^{\circ} \mathrm{C}$, when the top is warmer than the girder bottom, and $6^{\circ} \mathrm{C}$ in the reverse situation.

Figure 1 taken from Eurocode shows the suggested temperature profile between the upper and lower surface of the girder with regard of the nonlinear component of temperature difference.

According to Eurocode, the component of temperature difference $\Delta T$ is summed up with homogenous temperature component $\Delta T_{u}$, which 


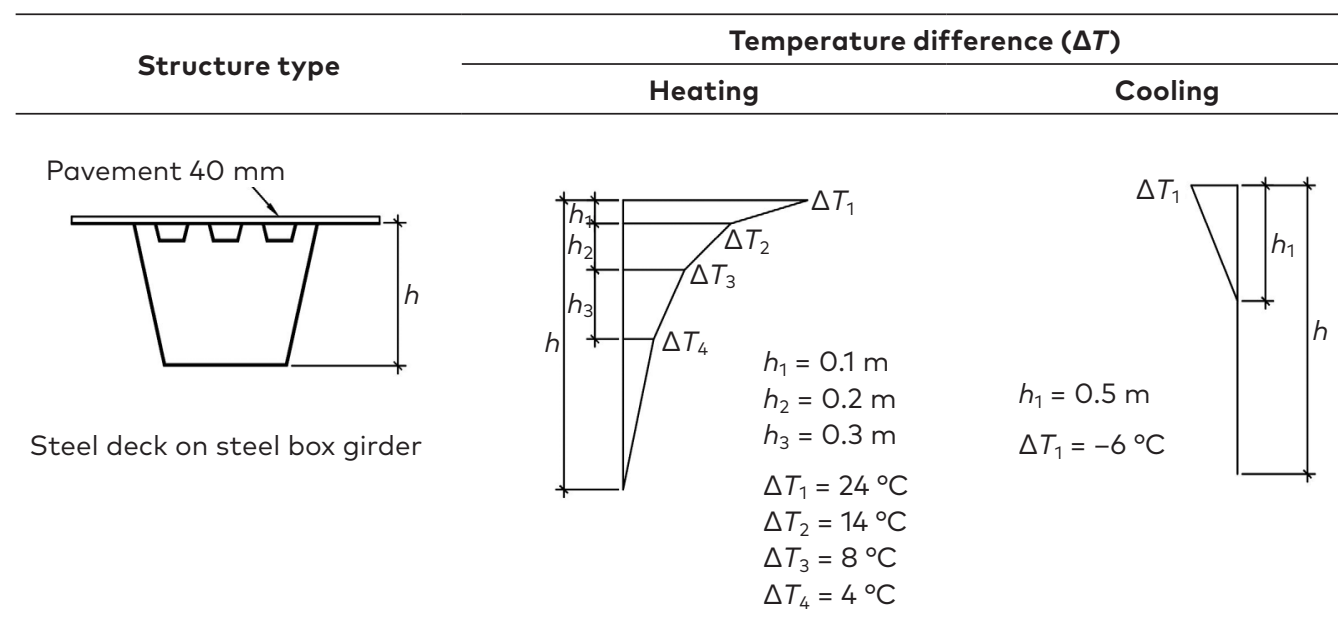

Figure 1. Recommended profile of temperature difference in a steel girder in vertical direction acc. to Eurocode 1 (2005) (refers to situation when the bridge pavement is $40 \mathrm{~mm}$ thick

is obtained from extreme air temperatures in the shade over the area where the structure is located. For example, the highest temperature in the middle and eastern part of the European Plain amounts to about $+36{ }^{\circ} \mathrm{C}$. Then, using respective nomogram of Eurocode, we can find the highest value of homogenous component of the maximum temperature of steel bridge structure - it is equal to $+52{ }^{\circ} \mathrm{C}$. While finding the highest temperature of extreme fibres considering the variable component (linear and nonlinear variables together), we should sum up the two components: $+52{ }^{\circ} \mathrm{C}$ and $+24{ }^{\circ} \mathrm{C}$. Thus, the result is $+76{ }^{\circ} \mathrm{C}$. While examining the reverse situation, i.e. while finding the lowest temperature of extreme fibres during cooling, and assuming the lowest air temperature equal to $-30^{\circ} \mathrm{C}$, and based on Eurocode nomogram, the lowest homogenous component of structure temperature of $-32{ }^{\circ} \mathrm{C}$ and the variable component of $-6^{\circ} \mathrm{C}$ (vide Figure 1) are found. As a result, the expected temperature in extreme and the coolest fibres of deck structure amounts to $-38^{\circ} \mathrm{C}$.

In view of Figure 1 from Eurocode 1, it is worth mentioning that thermal action of solar radiation during steel girder heating comprises the elements, which are situated in relatively shallow position below the bridge deck, i.e. several dozens of centimetres. When considering the spans of structural height $3 \mathrm{~m}$ to $4 \mathrm{~m}$, an essential thermal effect covers usually less than $20 \%$ of the cross-section height. 
The models and parameters included in Eurocode were to a large extent developed on the grounds of Mary Emerson's works included in the Fundamentals of Design Requirements (Emerson, 1977) based on examination results for bridges located in Great Britain at latitude about $50-52^{\circ} \mathrm{N}$. As concerns steel box bridges with pavement $40 \mathrm{~mm}$ thick, the maximum temperature difference along span height was determined to be equal to $24{ }^{\circ} \mathrm{C}$. At the same time, it was found that the highest temperature differences along the main girder height of steel bridges occurred when the effective bridge temperature is not less than $+25^{\circ} \mathrm{C}$. This work also demonstrated, for steel box bridges, that thermal action due to heating with solar radiation reaches no deeper than about $0.5 \mathrm{~m}$ below the deck level, (i.e. the temperature increment at this height of the section, during heating process with solar radiation, is not higher than $10 \%$ of the temperature increase at the top slab of the span).

In order to compare the data from measurements, it is worth focusing now on the results of examinations of the selected bridge located in the tropical zone.

An interesting work on the considered issue was published by Ostapenko (1975), examining a large steel box bridge located close to Rio de Janeiro at latitude of $22.5^{\circ} \mathrm{S}$. According to field examinations of the bridge connecting Rio de Janeiro with Niteroi Town, it was found that essential effect of heating the steel structural elements reaches no deeper than about $25 \mathrm{~cm}$ below the bridge deck, and the temperature increment of the top slab during its heating in a day amounts to about $20^{\circ} \mathrm{C}$. At the same time, the temperature increase of the bottom slab of the box girder is merely $5{ }^{\circ} \mathrm{C}$. However, we need to take into consideration that although the bridge is located in the hot climate zone, it is located right on the seashore of the Atlantic Ocean, which soothes the temperature of the surrounding air. The key conclusion of the tests is the fact that temperature profile creates a straight line almost along the full height of girders, excluding the above-mentioned $25 \mathrm{~cm}$ (Figure 2). It is worth adding that Chen (2008) investigated a series of bridges under similar insolation conditions, although in the northern hemisphere.

Bearing in mind the results of testing and analyses considered above, measurements were carried out for the steel box bridge outlined below, which is located in the European Plain in the zone of moderate transient climate.

Thus, the investigation results of temperature distribution in various bridges over the world are available, and the main knowledge gap, which the authors tried to bridge partially by means of research work outlined in this paper, consists in the lack of available measurement results for uneven heating of steel bridge constructions in Central and Eastern Europe. The results of such measurements can become a scientific 


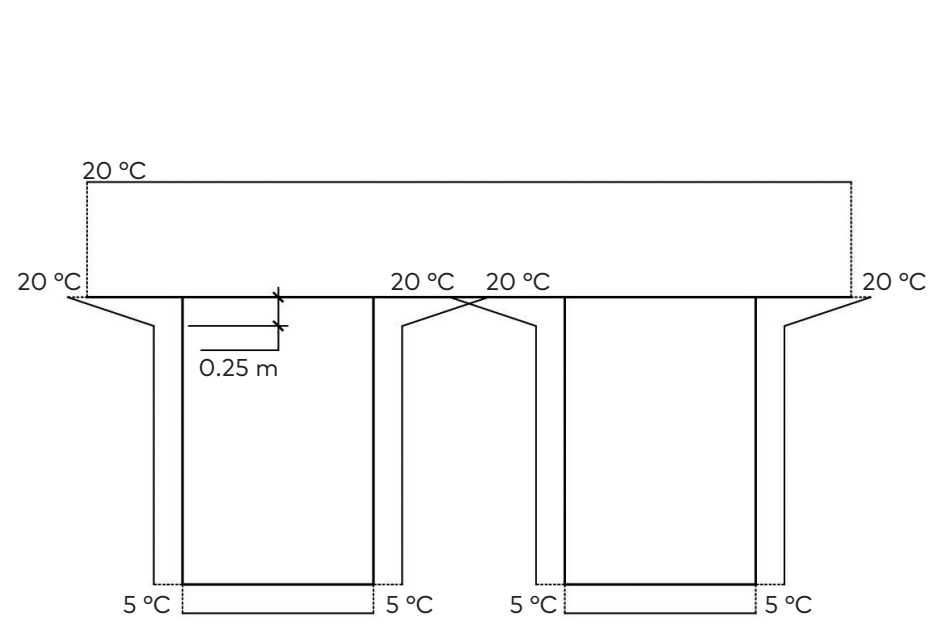

Maciej Hildebrand,

Figure 2. Temperature diagram of Rio-Niteroi bridge, recommended for climatic region of Rio de Janeiro, based on Ostapenko, (1975)

basis for revision of the National Annexes to the Eurocodes including clarification of the Nationally Determined Parameters, and they may become a supplement to the knowledge base in the respective research field. Moreover, the authors tried to use various measurement methods simultaneously, without limiting themselves to most frequently used and commonly known sensors based on thermocouples.

\section{The bridge under examination}

Examinations have been carried out for a steel box cable-stayed bridge operated since 2007 that includes theoretically the largest span in Poland equal to $375 \mathrm{~m}$. The project was described by Hajdin et al. (2004). This bridge spans over the Vistula River in Płock, Poland. Since 2005, the river current part of the structure has been continuously monitored. Continuous measurements include forces in stays, rotations of pylon tops, strains in steel structural components, environmental actions, i.e. velocity and direction of wind. Since 2011, the system has been expanded to include temperature sensors of steel structure and air inside the main span.

The bridge is composed of a $585 \mathrm{~m}$ long multi-span beam part on the left-bank flood plain, $615 \mathrm{~m}$ long main part with cable-stayed spans and $510 \mathrm{~m}$ long multi-span beam part over the land on the right bank. A single steel box three-cell girder, $27 \mathrm{~m}$ wide and about $3.5 \mathrm{~m}$ high, was used in the cable-stayed part including five spans. The main part of the river crossing is supported with stays positioned in a single plane. Elements of spans and both pylons are made totally 


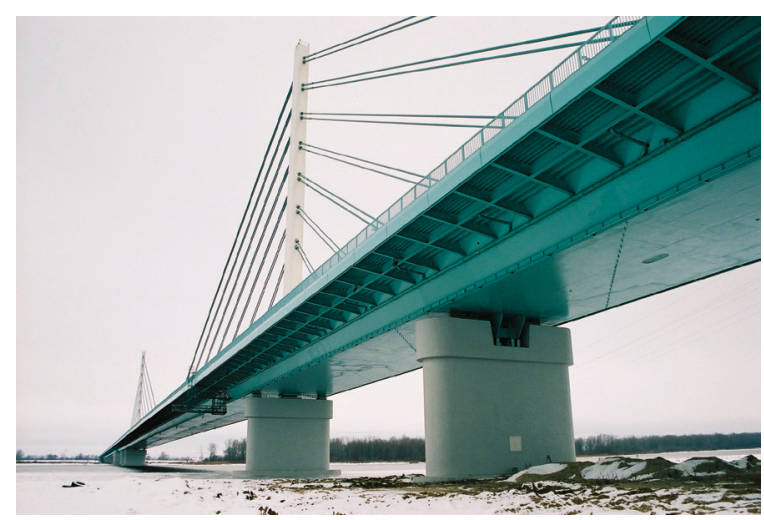

Figure 3. General view of the bridge

out of orthotropic plates. Two roadways and two bicycle/pedestrian paths are arranged on the bridge deck. The Vistula River runs in one compact riverbed about $460 \mathrm{~m}$ wide within the crossing, and both river banks are partially wooded or shrubby, the steel structure is painted in light green. The pavements of roadways and median strip are bituminous, while bicycle/pedestrian paths have a resin surface. Span underside is about $12 \mathrm{~m}$ above water table. General view of the bridge is given in Figures 3 and 4.

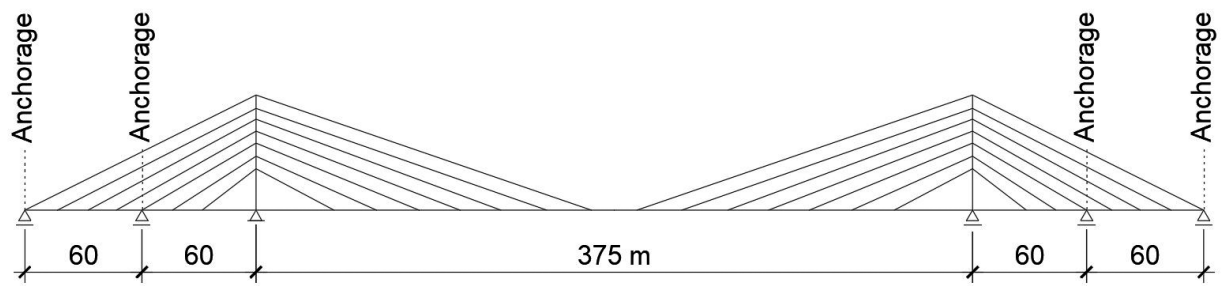

Figure 4. Static scheme of the cable-stayed part of the bridge with span sizes, units in $\mathrm{m}$

\section{Spot temperature measurements of the main span in structural health monitoring system}

Temperature of the steel structure is continuously taken in two points on the deck plate $\left(T_{3}\right)$ and bottom plate $\left(T_{2}\right)$ of the main girder, while air temperature is measured in the central cell of the girder 
$27.5 \mathrm{~m}$

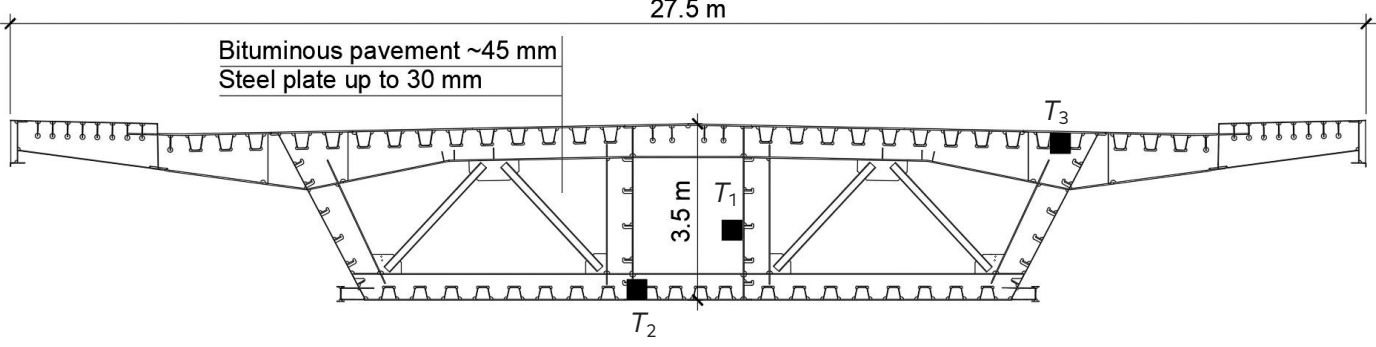

Figure 5. Location of permanent temperature sensors in the girder

(Figure 5). The $T_{3}, T_{2}$ and $T_{1}$ thermometers are located in the main span. Horizontal distance from the thermometers to the left river bank is over $60 \mathrm{~m}$. The $T_{3}$ and $T_{2}$ thermometers are directly attached to the surfaces of the upper and lower plates covered with anti-corrosive coating, both on the internal side of the box girder.

On the deck above the measurement points, from the top side, i.e. opposite to the temperature sensor, there are primer, intermediate layer, bonding layer and hard gussasphalt surface $45 \mathrm{~mm}$ thick. On the bottom side of the steel plate, i.e. from the side of temperature sensor, there is a three-layer paint coating.

Data from sensors in such layout enable to receive information on absolute values and temperature differences between the top and bottom slabs of the box girder. Temperatures of the top and bottom slabs vary both in the daily and annual cycles. Examples of daily temperature variations of the top and bottom slabs and the differences between them are given in Figures 6 and 7. These figures show diagrams for days with thermographic examinations outlined in the successive sections of the paper.

Analysing the temperature graphs, it should be taken into consideration that on the test day, i.e. 1 April 2019, there was a cloudless weather, both at night and during the day. Atmospheric air temperature around the bridge at sunrise (time 6:15) was about $-2.0{ }^{\circ} \mathrm{C}$, the temperature difference between the top and bottom slabs was $14.1{ }^{\circ} \mathrm{C}$ at its maximum about $15: 30$, and amounted to $11.5{ }^{\circ} \mathrm{C}$ at $13: 30$.

Slightly different values were observed during a hot day at the beginning of the summer, i.e. 26 June 2019, when atmospheric air temperature around the bridge at sunrise (time $4: 30$ ) was about $+21^{\circ} \mathrm{C}$, and about $+33.0{ }^{\circ} \mathrm{C}$ at $13: 30$. The temperature difference between the upper and lower slabs reached its maximum at c. 15:00 and amounted to $17.5^{\circ} \mathrm{C}$, whereas this difference was $15.2^{\circ} \mathrm{C}$ at $13: 30$. 


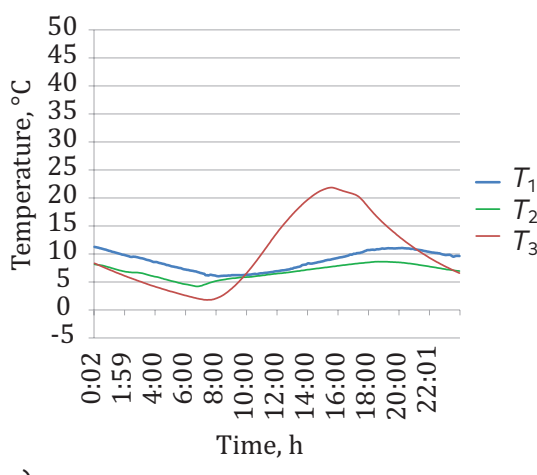

a)

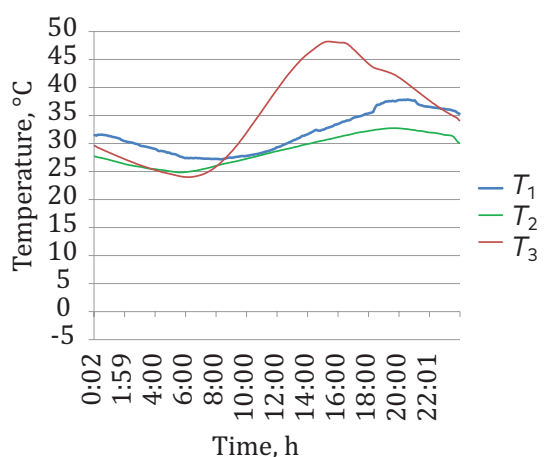

b)

Figure 6. Daily temperature graph of the top slab $\left(T_{3}\right)$, bottom slab $\left(T_{2}\right)$ and air inside the girder $\left(T_{1}\right) ;$ a) 1 April 2019, b) 26 June 2019

This measurement system including just two thermometers could not provide any more detailed information. Temperature distribution along the main girder height, i.e. along the height of the internal wall of the box girder, can be determined with dissipated thermocouple sensors, pyrometry, thermography or other method.

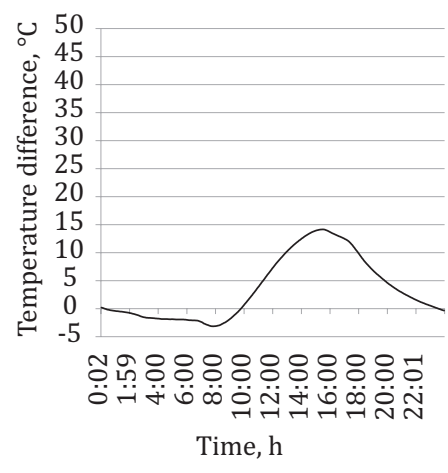

a)

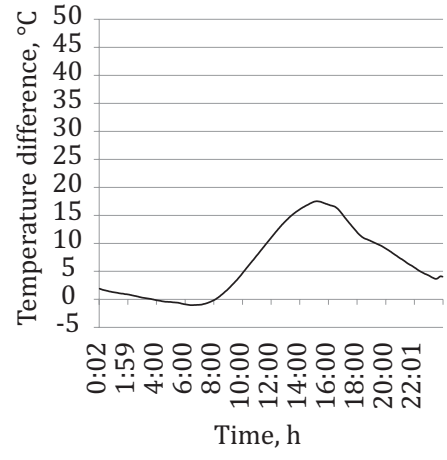

b)

Figure 7. Temperature difference between the top slab and bottom slab $T_{3}-T_{2}$; a) 1 April 2019, b) 26 June 2019 


\section{Thermovision measurements}

\subsection{General}

Thermovision examinations belong to the group of non-destructive testing (NDT) methods, i.e. the methods that allow detecting material defects or determining properties of an element or structure without introducing permanent changes into their material features and without their destruction. Apart from usage in construction industry, they are also widely applied in medicine, power engineering, heating industry, electronics, other industries or even in salvage services. This was discussed by Nowak (2012). Thermography in building engineering is first and foremost used for qualitative assessment of building partitions with respect of proper installation of thermal insulation, however it is more and more widely used also for assessing other properties. This method is especially applicable when:

- a construction is hardly accessible,

- object to be examined is a historic building and/or intervention into structure is not recommended,

- measurements should be made many times at various points of the structure or element.

Thermovision measurements of temperature at the surface of structural elements may be used to assess how extensive phenomena affecting durability or load capacity of a structure are, including, for instance, delamination, structural cracks or location of air voids. This was discussed by Vaghefi et al. (2012). However, even the assessment of temperature field over structure surface under examination may be valuable information, and this is the main topic of this paper. Uneven temperature distribution over structure surface may be caused by weather conditions, such as air temperature, solar radiation, wind or precipitation, and has a significant impact on the internal forces in the structure and its deformations.

Measurements were taken inside the girder, the section of the main span where temperature is spot-wise taken within the bridge monitoring system (vide Figure 5). A series of photos were made in order to determine temperature fields both in the slabs (top and bottom) of the box girder and in the vertical walls. Thermal imaging camera Flir ThermaCAM P65 was used. Its technical data were as follows: angle of view of the lens $24^{\circ}$, detector resolution $320 \times 240$ pixels, measuring accuracy $\pm 2{ }^{\circ} \mathrm{C}$ or $\pm 2 \%$ of readout, temperature range set to $-40{ }^{\circ} \mathrm{C}$ to $+120{ }^{\circ} \mathrm{C}$, emissivity set to 0.88 (determined by measurements). Recording was made mainly using a tripod, or with a hand-held way when tripod could not be positioned.
Distribution Within

Steel Box Girder

of Vistula

River Bridge

in Central Europe 


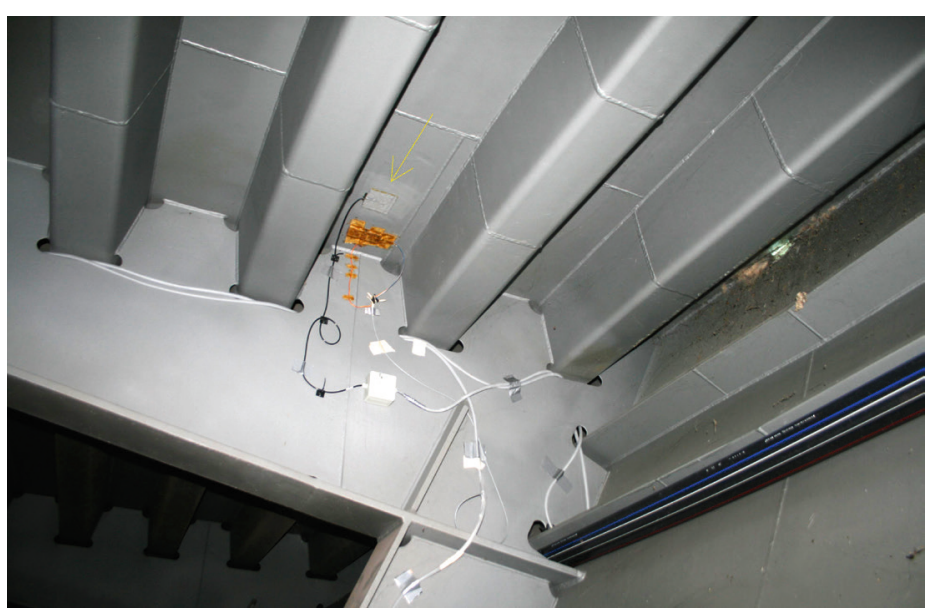

Figure 8. Photo of girder interior (connection of the top slab with external slanted wall), arrow shows point-wise temperature sensor of the top slab $T_{3}$

Figure 8 shows a photo of a structural node, i.e. a joint of the top slab with the internal transverse rib and external slanted wall, while Figure 9 provides an example of the thermogram made late in the evening of 31 March 2019.

An exemplary thermogram in Figure 9 clearly shows local temperature distribution close to the structural node inside the box girder. Heat accumulated during the day in construction elements is moved to atmosphere, the plates of external sheathing cool at the highest speed. When the photo was taken (night, time 23:00), it was a cloudless

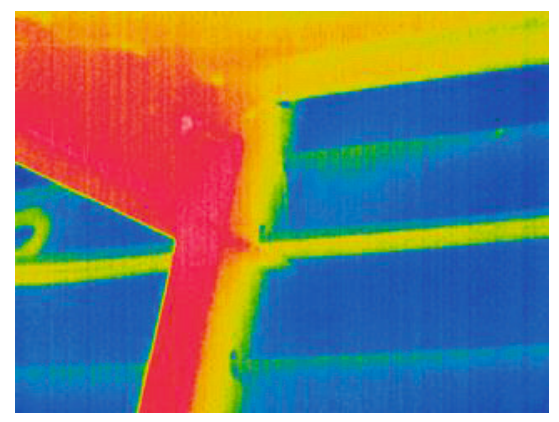

Figure 9. Thermovision photo of girder interior (cf. Figure 8). The photo taken on 31 March 2019 at about 23:00. Blue colour denotes cooler areas than those in yellow or red. Plates of the slanted wall of the girder dissipate heat outside faster than internal constructional elements like ribs 
weather, external temperature was about $+5.0^{\circ} \mathrm{C}$, air temperature inside Distribution Within the box girder was $+11.5^{\circ} \mathrm{C}$, temperature of the top slab was $+9.6^{\circ} \mathrm{C}$, and that of the bottom slab $+8.5^{\circ} \mathrm{C}$.

Using the mentioned thermovision method, the temperature Steel Box Girder of Vistula distribution in the vertical web of the box girder for two seasons was determined, namely: at the end of the cold season, i.e. at the turn of March and April, and at the beginning of summer, i.e. in the second half of June. In both cases, a cloudless and windless weather both at night and at day was expected. In both cases the measurements were taken three times: (i) several hours after sunset, (ii) at sunrise, and (iii) at the peak of insolation, shortly after noon.

\subsection{Measurements during cold season}

In order to determine temperature distribution along the height of the girder during the warmest daytime at the end of the cold season, the thermographic photos were made at 13:30 on 1 April 2019. The
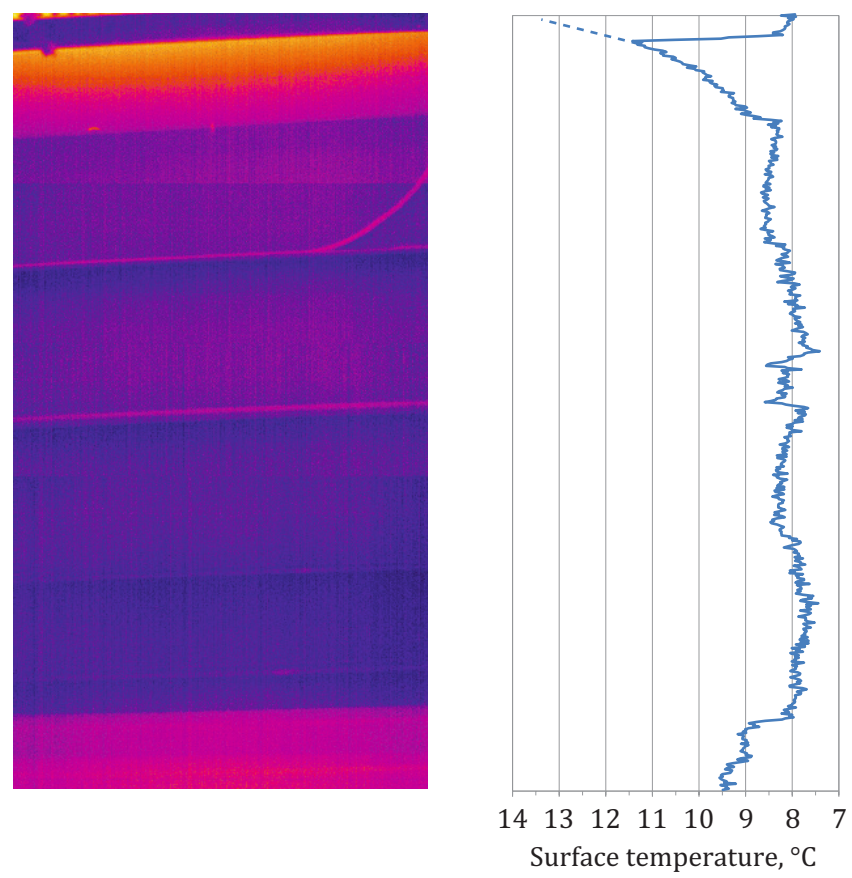

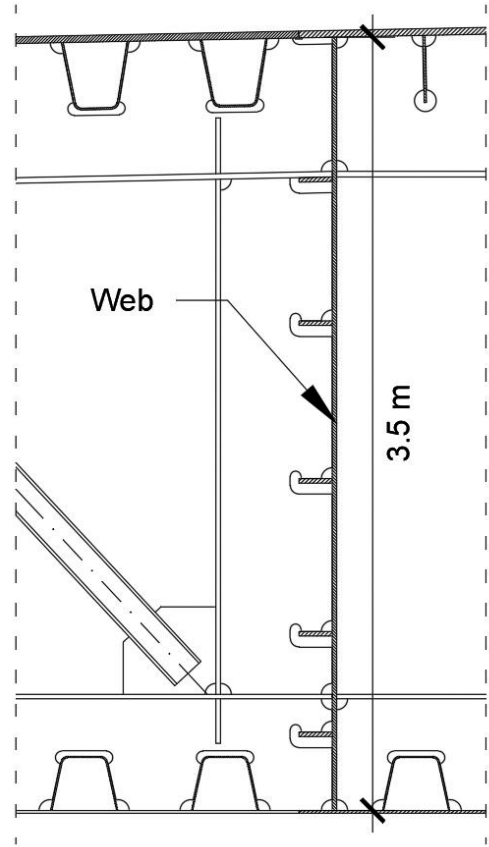

Figure 10. Thermogram and temperature profile of internal web, 1 April 2019, time 13:30. Effect of heating with solar radiation on the deck is visible in the upper part of element only. Extrapolation of the temperature curve is proposed (broken line) 
weather was sunny, external temperature was c. $+9{ }^{\circ} \mathrm{C}$, temperature of the air inside the box girder was $+7.8^{\circ} \mathrm{C}$. Spot measurements made with thermometers $\left(T_{3}\right.$ and $\left.T_{2}\right)$ showed $+18.4{ }^{\circ} \mathrm{C}$ for the top slab and $+7.0^{\circ} \mathrm{C}$ for the bottom slab. Thermographic photo taken under these conditions is shown in Figure 10 together with temperature profile determined from this photo. The photo demonstrates that temperature of the greater part of the web is about $+8^{\circ} \mathrm{C}$, while close to the bottom slab, the temperature is higher and reaches c. $+9.5^{\circ} \mathrm{C}$. In the upper zone of the steel web under observation, the temperature comes to about $11.5^{\circ} \mathrm{C}$. The photo does not include horizontal plate of the top slab and its contact with the web considered because this area is covered by a rib of the deck orthotropic plate, hence the highest temperature of the web was not recorded in this thermogram. However, it should be pointed out that distinct rise of web temperature caused by contact effect of the deck plate heated by the sun is observed just only in its upper zone with the height less than $0.5 \mathrm{~m}$, while the total height of the web is $3.5 \mathrm{~m}$. Measurements were also made during the night and in early morning. The results are summarised in Section 4.4.

Note: Colour palette used in the thermogram in Figure 10 is not identical with that used in the thermogram in Figure 11. The scale of colours is automatically selected by thermal imaging camera for each individual photo.

\subsection{Measurements during warm season}

In order to determine temperature distribution during the day at the beginning of warm season, thermographic photos were taken on 26 June 2019 at 13:30 in sunny weather; external temperature was about $+33^{\circ} \mathrm{C}$, while air temperature inside the box girder was $+30.4{ }^{\circ} \mathrm{C}$. Spot measurements made with thermometers $\left(T_{3}\right.$ and $\left.T_{2}\right)$ showed $+45.4{ }^{\circ} \mathrm{C}$ for the top slab and $+29.8{ }^{\circ} \mathrm{C}$ for the bottom slab. Thermographic photo taken under these conditions is shown in Figure 11 together with temperature profile determined from this photo. Thus, it is clear that for the greater part of the web - close to $3 / 4$ of its total height - temperature ranged from $+31.0^{\circ} \mathrm{C}$ to $+33.0{ }^{\circ} \mathrm{C}$. In the top part of the web, about $0.5 \mathrm{~m}$ high, the temperature was from $+35^{\circ} \mathrm{C}$ to $+45^{\circ} \mathrm{C}$. Temperature of the middle and bottom part of the web and the bottom slab was not substantially different from external air temperature.

Measurements were also made during the night, i.e. several hours after sunset and in early morning, i.e. at sunrise. (See Section 4.4). 

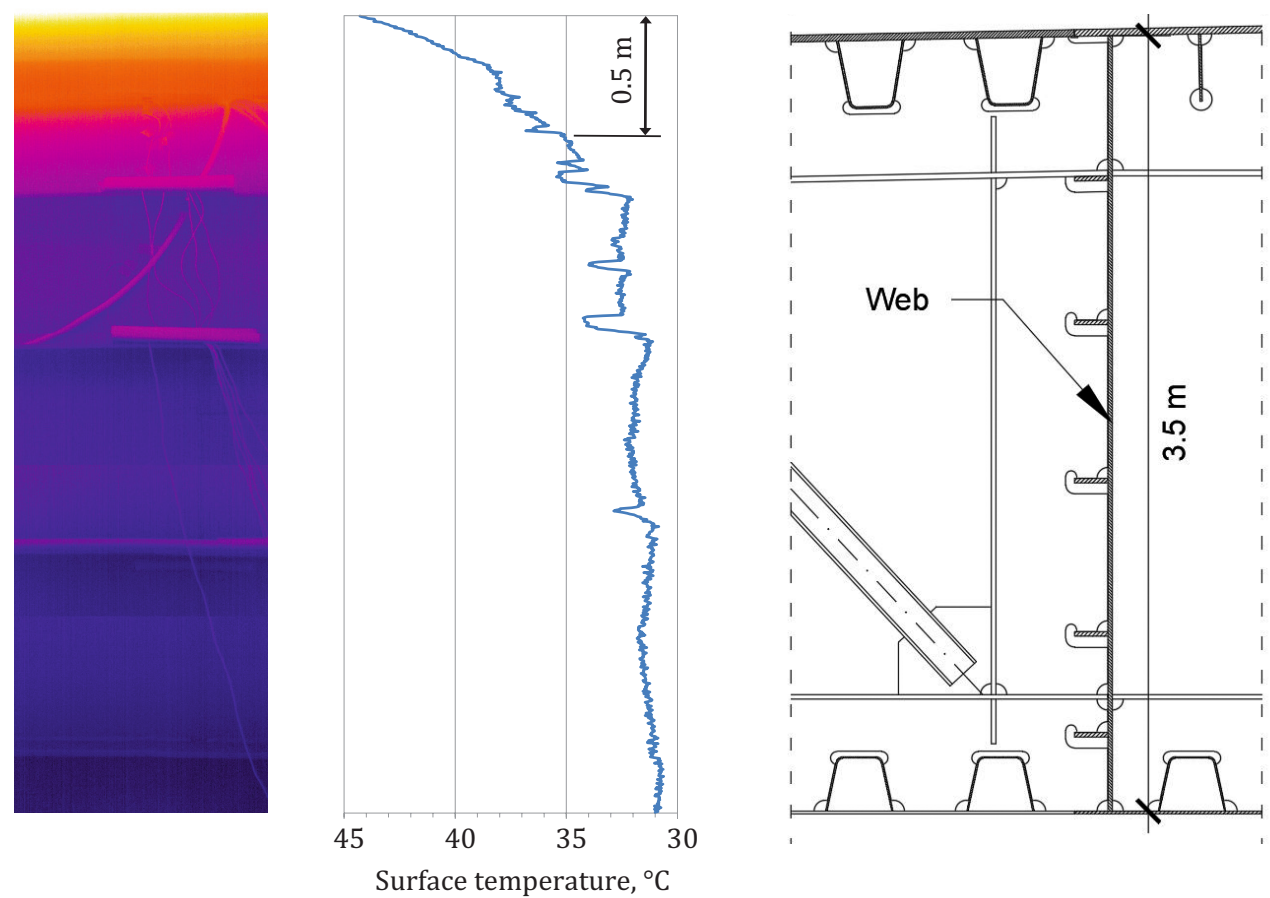

Figure 11. Thermogram and temperature profile of the internal web, 26 June 2019, time 13:30. Visible effect of solar heating - high temperature in the upper part of the web

\subsection{Summary of measurement results}

The summary of temperature measurements is given in Table 1. It shows temperatures of the top slab $\left(T_{3}\right)$, bottom slab $\left(T_{2}\right)$, internal air $\left(T_{1}\right)$, external air $\left(T_{\text {ext }}\right)$, temperature difference $\left(T_{3}-T_{2}\right)$ at the moment under consideration, weather condition, i.e. cloudiness expressed as a fraction with denominator of 10 , and simplified diagrams of temperatures taken from thermograms at the moments analysed. It should be emphasized that for all cases the sky was cloudless or lightly clouded, wind was weak or there was silence. Normal car traffic typical for weekdays was observed on the bridge. 
Table 1. Temperatures taken in the main steel box girder of the bridge

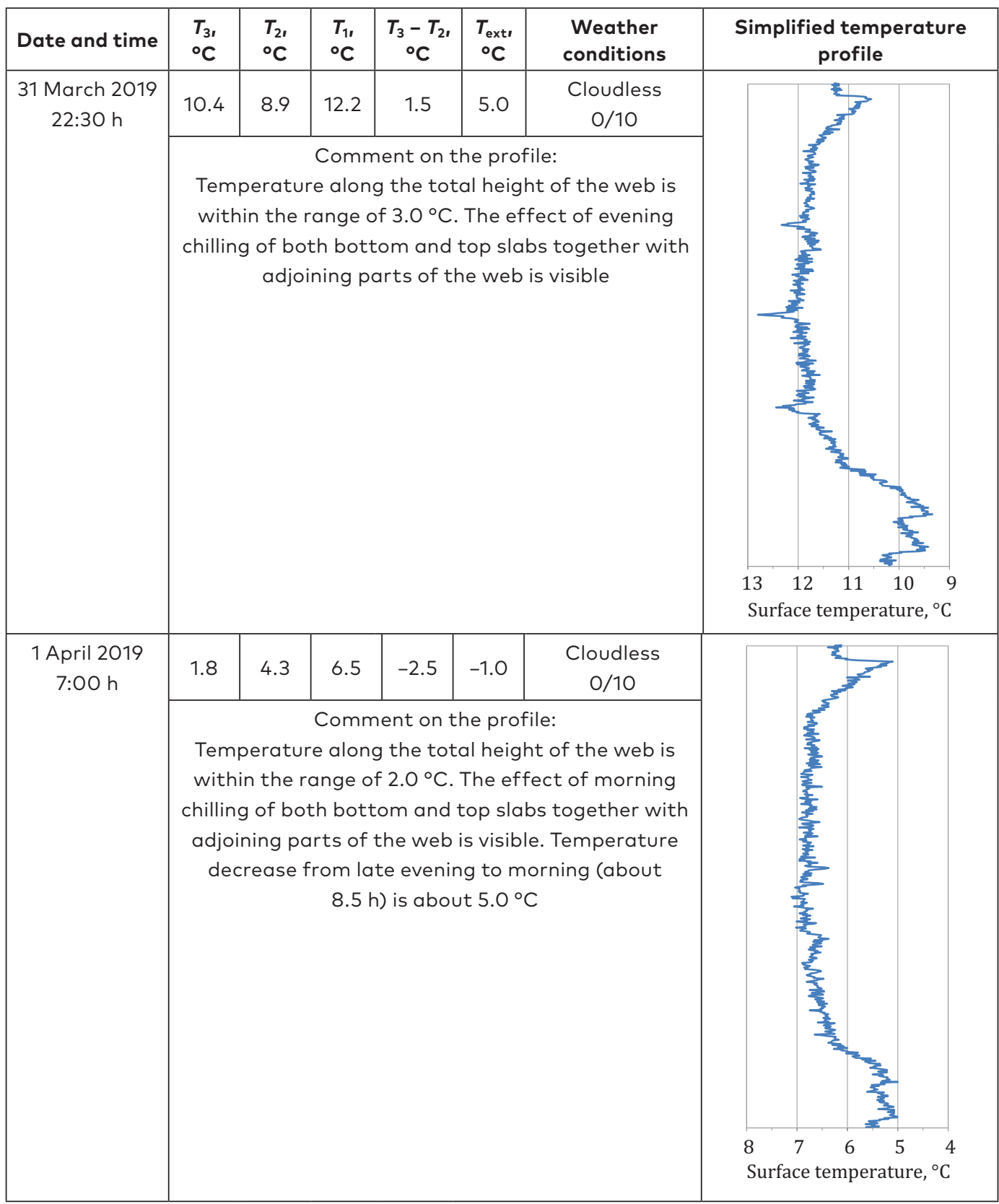


Table 1. Continuation

\begin{tabular}{|c|c|c|c|c|c|c|c|}
\hline Date and time & $\begin{array}{l}T_{31} \\
{ }^{\circ} \mathrm{C}\end{array}$ & $\begin{array}{l}T_{21}, \\
{ }^{\circ} \mathrm{C}\end{array}$ & $\begin{array}{l}T_{1}, \\
{ }^{\circ} \mathrm{C}\end{array}$ & $\begin{array}{l}T_{3}-T_{2} \\
{ }^{\circ} \mathrm{C}\end{array}$ & $\begin{array}{l}T_{\text {ext' }} \\
{ }^{\circ} \mathrm{C}\end{array}$ & $\begin{array}{l}\text { Weather } \\
\text { conditions }\end{array}$ & $\begin{array}{c}\text { Simplified temperature } \\
\text { profile }\end{array}$ \\
\hline \multirow[t]{3}{*}{$\begin{array}{l}1 \text { April } 2019 \\
\text { 13:30 h }\end{array}$} & 18.4 & 7.0 & 7.8 & 11.4 & 9.0 & $\begin{array}{l}\text { Cloudless } \\
\text { 0/10 }\end{array}$ & \multirow{6}{*}{ 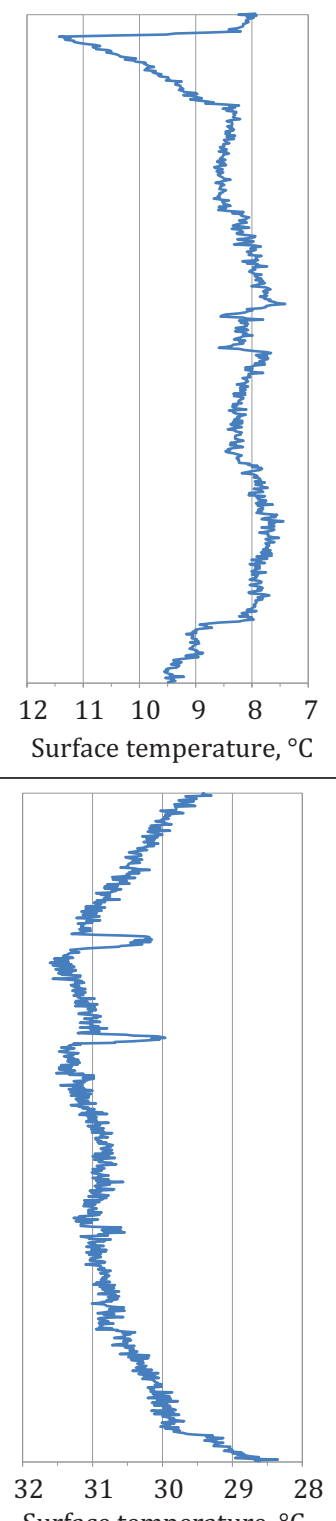 } \\
\hline & $\begin{array}{r}\text { Temp } \\
\text { solc } \\
\text { slab v } \\
\text { Are } \\
\text { abo } \\
\text { heate }\end{array}$ & $\begin{array}{l}\text { ratu } \\
\text { radi } \\
\text { th im } \\
\text { no } \\
\text { of in } \\
0.5 \\
\text { up }\end{array}$ & $\begin{array}{l}\text { Comr } \\
\text { rise o } \\
\text { ion is } \\
\text { ediat } \\
\text { ecord } \\
\text { eased } \\
\text { high. } \\
\text { pbabl) } \\
\text { the } r\end{array}$ & $\begin{array}{l}\text { ent on } t \\
\text { the top } \\
\text { isible. Te } \\
\text { ly adjac } \\
\text { d on th } \\
\text { temperc } \\
\text { Che lowe } \\
\text { due to } r \\
\text { er wate }\end{array}$ & $\begin{array}{l}\text { e pro } \\
\text { oart o } \\
\text { mperc } \\
\text { nt pa } \\
\text { thern } \\
\text { ture e } \\
\text { part } \\
\text { diatic } \\
\text { surfo }\end{array}$ & $\begin{array}{l}\text { he web due to } \\
\text { re of the top } \\
\text { f the web was } \\
\text { ram. } \\
\text { races a part } \\
\text { girder is also } \\
\text { eflected from }\end{array}$ & \\
\hline & & & & & & & \\
\hline \multirow[t]{3}{*}{$\begin{array}{l}26 \text { June } 2019 \\
\text { 0:00 h }\end{array}$} & 29.3 & 27.6 & 31.5 & 1.7 & 25.0 & $\begin{array}{l}\text { Cloudless } \\
0 / 10\end{array}$ & \\
\hline & \multicolumn{6}{|c|}{$\begin{array}{l}\text { Comment on the profile: } \\
\text { High temperature in the range of } 3.0^{\circ} \mathrm{C} \text { appears } \\
\text { along the whole height of the web. Effect of night } \\
\text { chilling of both top and bottom parts of the girder } \\
\text { is visible }\end{array}$} & \\
\hline & & & & & & & \\
\hline
\end{tabular}


Table 1. Continuation

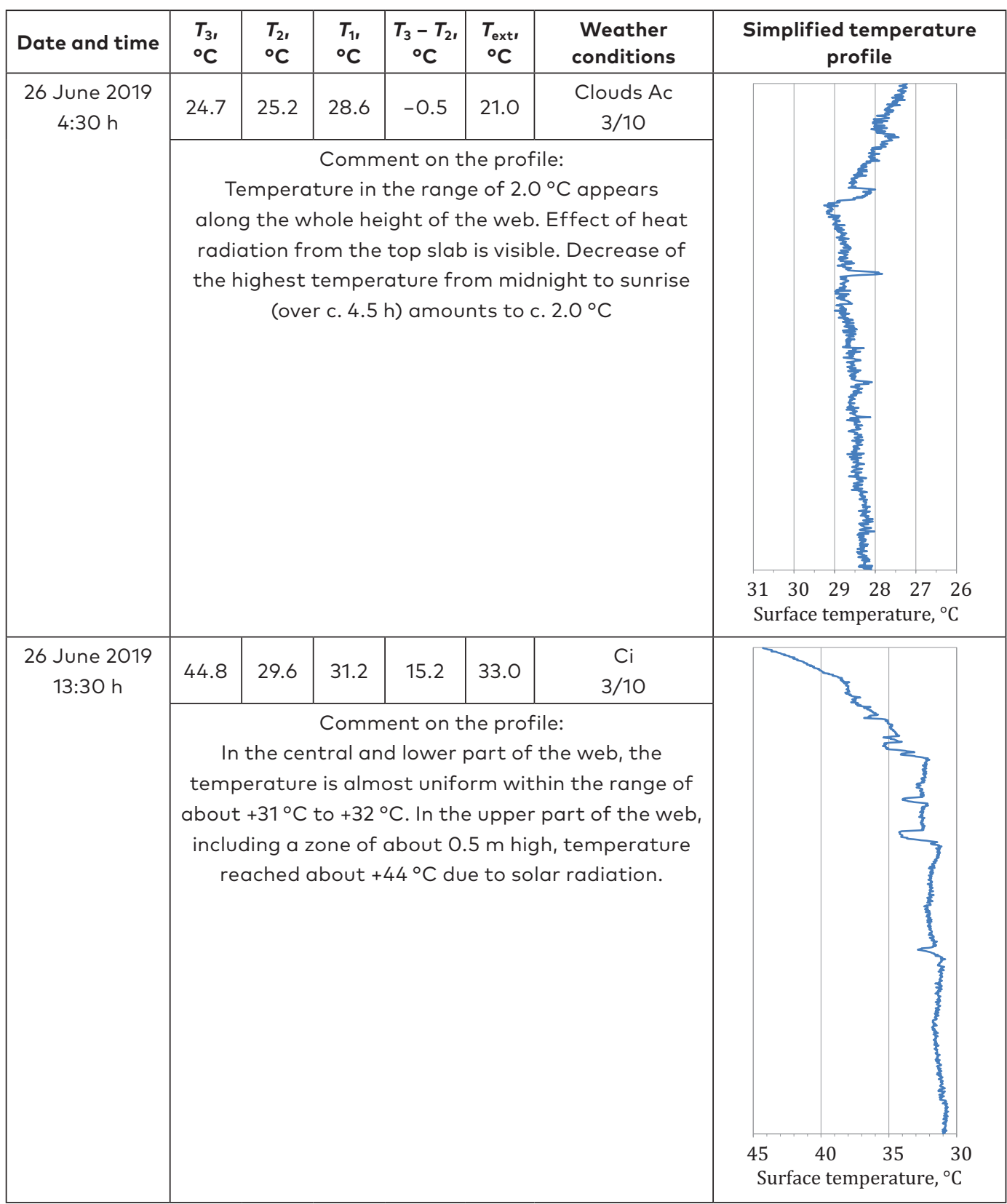


The last column of Table 1 provides selected temperature profiles Distribution Within Steel Box Girder characteristic for three times of the day in two different seasons. The most important information included in the profiles are the shapes of curves representing the values of temperature depending on the place on the height of the box girder web. It should be noted that the shapes of diagrams are weakly dependent on the seasons, but they are mainly dependent on the daytime. Obviously, temperatures recorded in the warm season are higher than those in the cold season, and temperature differences between the bottom and top plates are also higher during the warm season.

Two essential conclusions can be drawn from the above-presented results:

- with regard to available literature on the subject, it should be stated that general temperature distribution is similar to results obtained through other examinations over the world;

- in some guidelines and recommendations referring to temperature distributions in bridges, no considerations are made to disturbances of temperature profile in the lower part of bridge span, which actually exist.

\section{Comparing results obtained from spot thermometers and thermography}

While reviewing Table 1, we can find essential discrepancies between temperatures indicated by spot thermometers $\left(T_{2}, T_{3}\right)$ permanently installed on the top and bottom slab of the span and the temperatures determined by thermography. The sources of these discrepancies are as follows:

- temperatures measured with spot thermometers refer to areas at some distance from the web, which is subjected to thermographic testing, and the assumption that the temperature in the whole top slab is identical could not be justified;

- thermovision image for extreme heights and the lowest areas of the wall, which are in contact with the top slab and bottom slab respectively, is highly hampered due to ribs of the top and bottom slabs; this problem was stated during measurements on 1 April 2019 and was partially eliminated during measurements on 26 June 2019 by positioning the camera slightly closer the web and directing the lens a bit higher, and eliminating the possibility to measure the extreme lowest areas of the web, hence the results 
from June are more in line with spot measurements - see 26 June 2019, 13:30;

- thermovision images include a series of disturbances which should be interpreted by an experienced person in this field.

In late evening, night and early morning the temperature along the whole height of the main girder is quite levelled. The range, within which the temperature is included, independently of the season in this time of day, is about $2-3{ }^{\circ} \mathrm{C}$. Not until the noon and afternoon hours, this range gets wider to a dozen or so degrees. In extreme situations, it reaches even higher value.

\section{Control measurements and comparison of results with eurocode recommendations}

In order to verify the data, especially those referring to the upper parts of the web under examination, control pyrometric measurements were carried out, their results are given below. The pyrometer type Peak Tech 4975 Dual Laser IR Termometer was used.

Based on pyrometric measurements, it was stated that the following temperatures existed at the moment when the photos were taken (26 June 2019, time 13:30):

- top slab temperature: $46.6^{\circ} \mathrm{C}$;

- temperature at contact point between the web and top slab: $37.8^{\circ} \mathrm{C}$;

- web temperature at distance of $0.5 \mathrm{~m}$ from the top slab: $34.2^{\circ} \mathrm{C}$;

- web temperature at distance of $1.0 \mathrm{~m}$ from the top slab: $33.0^{\circ} \mathrm{C}$.

Diagram of particular temperatures is shown in Figure 12; the results of measurement are marked with red circles. It should be noted that while the maximum measured temperature, i.e. $+46.6^{\circ} \mathrm{C}$, is close to that recorded in the monitoring system (i.e. $+44.8^{\circ} \mathrm{C}$ in $T_{3}$ sensor) and similar to that found in thermogram $\left(+44.0^{\circ} \mathrm{C}\right)$, the temperatures recorded at web/slab contact and slightly below are definitely lower. Just $+37.8^{\circ} \mathrm{C}$ was recorded at web/top slab contact, whereas $+44.0^{\circ} \mathrm{C}$ was read in the thermogram for this point. This discrepancy is currently being analysed. We can only assume that these discrepancies are caused by local heat radiation reflections.

It should be noted that the results reached are generally consistent with the model of thermal load included in Eurocode. This consistency first and foremost refers to the size of the top area of the bridge girder subjected to heating. According to this model, temperature rise diagram is non-linear in the neighbourhood of the top slab; it covers girder area 
$0.6 \mathrm{~m}$ high as measured from the top slab, and the maximum value of Distribution Within the increment is $+24.0{ }^{\circ} \mathrm{C}$. Thermovision testing outlined in this paper also found the non-linear nature of temperature increase for the area covering about $0.5 \mathrm{~m}$, at the maximum value of $+13.0{ }^{\circ} \mathrm{C}$ according to Steel Box Girder of Vistula River Bridge thermovision, and $+7.0^{\circ} \mathrm{C}$ as per pyrometry (Figure 12). It can be pointed out that above mentioned measurements of temperature rise were taken at the highest position of the sun over the horizon, both on the scale of a day and the whole year, as they were made on the first days of summer. Furthermore, the weather was almost cloudless, i.e. there were cirrus clouds covering $3 / 10$ of the sky and there was no substantial wind $(1 \mathrm{~m} / \mathrm{s}$ to $5 \mathrm{~m} / \mathrm{s}$ ).

External air temperature of $+33.0^{\circ} \mathrm{C}$ may be considered high as per geographic conditions surrounding the bridge under examinations. Hence, the testing conditions could be estimated as advantageous to run respective analyses and could be referred to other bridges located in the European Plain at the latitude of about $52.5^{\circ} \mathrm{N}$.

It should be added that general consistency was also found in relation to girder structure chilling during the night. In accordance with the

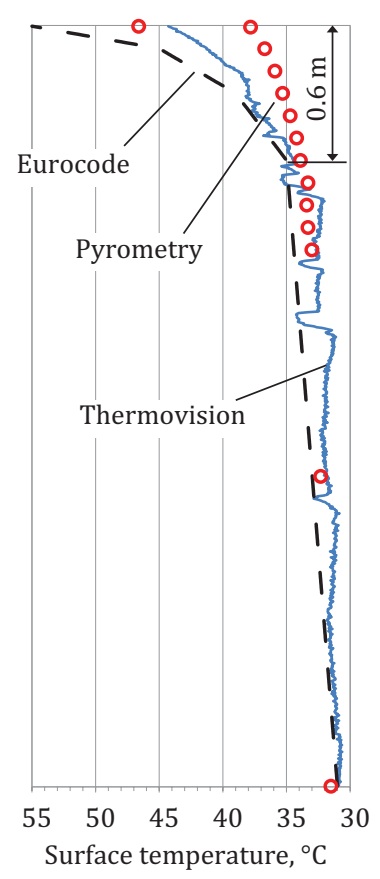

Figure 12. Comparison of results from thermovision and pyrometry with the model of Eurocode, 26 June 2019, time 13:30, in relation of girder heating 
model from Eurocode, temperature reduction diagram covers the girder area $0.5 \mathrm{~m}$ high as measured from the top slab, the extreme value of temperature reduction is $-6.0^{\circ} \mathrm{C}$.

Thermovision examinations have shown that certainly there is a cooled down zone of about $0.5 \mathrm{~m}$ high in the upper part of the span, but there is also a cooled down zone of about $0.8 \mathrm{~m}$ high in the lower part of the span. The difference of temperatures between the bottom slab and the central part of the web is similar to that between the central part of the web and the upper plate (Figure 13). This phenomenon was also mentioned in Chen's dissertation (2008).

This phenomenon is not mentioned in the model given in Eurocode either. Likewise, no information was given about possible heating of the main girder in its lower zone, which was found in the examinations presented above. It should also be noted that there are disturbances corresponding to the longitudinal ribs of the web under investigation in the thermograms taken.

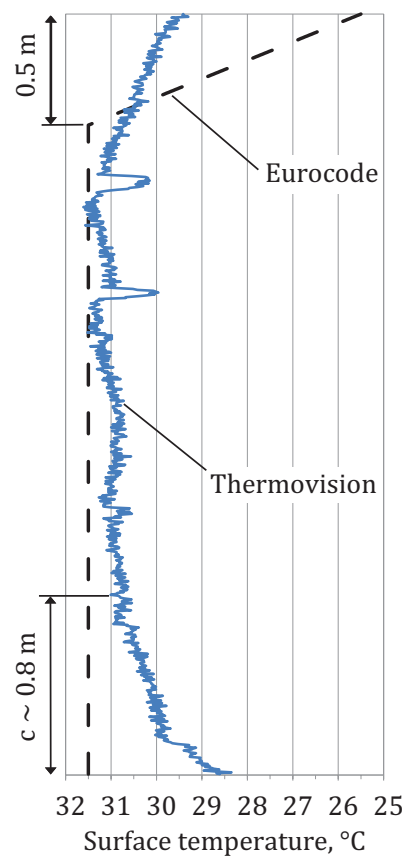

Figure 13. Comparison of testing results with the model from Eurocode based on thermogram of 26 June 2019, time 0:00, in relation to girder chilling 


\section{Final remarks}

As a result of examinations carried out, the following findings have been made:

- thermovision methods can be applied to assess temperature distribution in components of bridge structures;

- corresponding experience is required to interpret and approve the results of temperature examinations;

- it is highly advisable to run parallel, partially duplicating measurements, using other method in order to increase credibility of thermograms taken;

- a thesis is proposed that resolution of thermovision methods should be high enough to allow for proper reflection of temperature distribution in the corners and other areas of complicated shapes;

- the results obtained for temperature distribution in the main girder are not in contradiction with the model from Eurocode, although temperature differences in our examinations are not as large as those proposed in the standard;

- Eurocode does not point to eventuality of heating or chilling the lower parts of the girder, although this phenomenon indeed exists.

Examining temperatures with contactless thermometers and with thermovision methods allows for essential shortening the time of measurements, but credibility of testing should be verified by doubling measurements taken with other methods.

Here, we need to add a comment on incomplete consistency of results from measurements carried out with various methods. The authors are aware that results from thermographic, pyrometric and contact methods are not completely compatible. The issue needs closer examination, however, a hypothesis is proposed that non-contact methods are more sensible to disturbing radiation reflections resulting from, for instance, complicated shape of elements under examination. At the same time, a thesis is advanced that the problem can be limited by optimizing the position of thermovision camera with respect to the element tested and by taking photos of limited (smaller) parts of the object under examination.

The findings summarize the first step of research undertaken to develop a measurement methodology aiming at elaborating or detailing the National Annexes to Eurocodes including the Nationally Determined Parameters.
Distribution Within

Steel Box Girder

of Vistula

River Bridge

in Central Europe 
A global data base of thermal phenomena in bridges should be based on the results of local measurements, which are affected by both geographic conditions and local routines used in bridge design and construction, including construction materials, forms and equipment used for bridges.

\section{REFERENCES}

Albrecht, G., Mangerig, I., Zichner, T. (1992). Warmewirkungen für Strassen- und Eisenbahnbrucken. Der Ingenieurgemeinschaft HRA-Koenig/Heunich/ Mangerig. (in German)

Chen, Q. (2008). Effects of Thermal Loads on Texas Steel Bridges. Doctoral dissertation, The University of Texas at Austin.

http://hdl.handle.net/2152/17802

Emerson M. (1977). Temperature Differences in Bridges: Basis of Design Requirements. Transport and Road Research Laboratory, Laboratory Report 765, Crowthorne, UK.

Eurocode 1. (2005). EN 1991-1-5, Action on structures, Part 1-5: General actions Thermal actions

Hajdin, N., Stipanic, B., Krawczyk, J., Wachalski, K. (2004). The Roadway Bridge over Vistula River in Plock (Poland). Proceedings of the $5^{\text {th }}$ International Conference on Bridges across the Danube, Bridges in Danube Basin, Euro Gardi Group, Novi Sad, 2004, 359-370.

Inaudi, D. (2009). Overview of 40 Bridge Structural Health Monitoring Projects. International Bridge Conference IBC 2010, June 15-17 2009, Pittsburgh, USA.

Nowak, H. (2012). Application of infrared thermography in building. Wrocław University of Science and Technology Publishing House, Wroclaw. (in Polish)

Opara, K., Zieliński, J. (2017). Road Temperature Modelling Without In-Situ Sensors. The Baltic Journal of Road and Bridge Engineering, 12(4), 241-247. https://doi.org/10.3846/bjrbe.2017.30

Ostapenko, A., Daniels, J. H., and Fisher, J. W. (1975). Field study on the President Costa e Silva Bridge (steel structure). Progress Report No. 3, May 1975. Fritz Laboratory Reports, 2099. Lehigh University, Lehigh Preserve.

Prakash, R. D. S. (1986). Temperature Distribution and Stresses in Concrete Bridges. ACI Journal, July - August 1986.

Priestley, M. J. N. (1978). Design of Concrete Bridges for Temperature Gradients. ACI Journal, May 1978.

Vaghefi, K. et al. (2012). Evaluation of Commercially Available Remote Sensors for Highway Bridge Condition Assessment. Journal of Bridge Engineering, 17(6), 886-895. https://doi.org/10.1061/(ASCE)BE.1943-5592.0000303

Wenzel, H. (2009). The character of SHM in Civil Engineering. In Boller, C., Chang, F.-K., Fujino, Y. (Eds.), Encyclopedia of Structural Health Monitoring (Chapter 118). John Wiley \& Sons. https://doi.org/10.1002/9780470061626.shm156 
Zhou, G.-D., Yi, T.-H. (2013). Thermal Load in Large-Scale Bridges: A State-of-the-Art Review. International Journal of Distributed Sensor Networks, Article ID 217983. http://dx.doi.org/10.1155/2013/217983

Zobel, H., Sobala, D. (2002). Temperatures and Thermal Movements of Polish Bridges. IABSE Symposium Report, 86, 56-64.

https://doi.org/10.2749/222137802796336630
Distribution Within Steel Box Girder of Vistula

River Bridge

in Central Europe 